\title{
THE PERCEPTION OF SIGNIFICANT ASPECTS OF PERSONNEL RISK IN THE MANAGEMENT OF SMEs
}

\author{
Jaroslav Belas, Jr. ${ }^{1, a, *}$, Katarina Zvarikova ${ }^{2, b}$, Josef Marousek ${ }^{3, c}$ and Zdenko \\ Metzker ${ }^{4, \mathrm{~d}}$ \\ ${ }^{1}$ Faculty of Social and Economic Relations, Alexander Dubcek University in Trencin, Studentska 3, \\ 91150 Trenčín, Slovak Republic \\ ${ }^{2}$ Faculty of Operation and Economics of Transport and Communication, Department of Economics, \\ University of Zilina, Univerzitna 1, 01026 Žilina, Slovak Republic \\ ${ }^{3}$ Faculty of Technology, Institute of Technology and Business in Ceske Budejovice, Okruzni 517/10, \\ 37001 České Budějovice, Czech Republic \\ ${ }^{4}$ Faculty of Management and Economics, Tomas Bata University in Zlín, Mostní 5139, 76001 Zlín, \\ Czech Republic \\ ajaroslav.belas@student.tnuni.sk, ${ }^{b} k a t a r i n a . z v a r i k o v a @ f p e d a s . u n i z a . s k,{ }^{c}$ marousek@mail.vstecb.cz, \\ dmetzker@utb.cz \\ *Corresponding author
}

Cite as: Belas, J. Jr., Zvarikova, K., Marousek, J., Metzker, Z. (2021). The perception of significant aspects of personnel risk in the management of SMEs, Ekonomicko-manazerske spektrum, 15(2), 1-12.

Available at: dx.doi.org/10.26552/ems.2021.2.1-12

Received: 13 April 2021; Received in revised form: 8 June 2021; Accepted: 28 June 2021; Available online: 30 December 2021

\begin{abstract}
:
Research background: The issue of personnel risk management has received less attention from scholars than other types of managerial risks. Employees represent important capital for an enterprise, which can significantly influence its performance and success

Purpose of the article: The aim of the study is to present and quantify significant factors of personnel risk in the SME sector. Part of the goal is to compare entrepreneurs' approaches to these factors based on company size and the entrepreneurs' education and age.

Methods: The empirical research was conducted on a sample of 250 respondents from Slovakia via an online questionnaire. The statistical hypotheses were tested using descriptive statistics (percentages) and Pearson's statistics (chi-square and Z-score).

Findings \& Value added: The research confirmed that personnel risk posed a significant business risk for SMEs, as up to $32 \%$ of all the respondents rated this risk as unacceptable. Neither employee turnover nor employees' error rate level represented a significant problem for SMEs at the time of the study. Only a small proportion of the respondents agreed with the opinion that their employees attempted to improve their performance, and that competition prevailed among them. The research demonstrated that some differences in entrepreneurs' overall attitudes related to their age and education. Additionally, differences were identified in the entrepreneurs' positive attitudes towards individual claims based on their education and age. Meanwhile, the results show that the issue of personnel management in the effective management of personnel risks in the SME environment could be an exciting issue for scientific research.
\end{abstract}




\section{The perception of significant aspects of personnel risk in the management of SMEs \\ Authors: Jaroslav Belas, Jr., Katarina Zvarikova, Josef Marousek Zdenko Metzker}

Keywords: small and medium-sized enterprises (SME), personal management, personnel risk, employees' fluctuation, employees' error rate

JEL Classification: L26, J24, M12, O15

\section{Introduction}

Although small and medium-sized enterprises (SMEs) are considered to have small economic power, they represent the main engines of the economy in both developing and developed countries (Meekaewkunchorn et al., 2021). Their positive impact is evident in, for example, the employment rate, state revenue (Kljucnikov et al., 2016), and the development of human capital (Meekaewkunchorn et al., 2021), where they are an essential part of strategic business services (Rocha, 2012). SMEs are generally considered to be a flexible, efficient, and progressive part of the economic system worldwide (Septimiu, 2020; Zuzek and Zvirbule, 2018; Kozubikova et al., 2017), with a significant share of the economy (Meekaewkunchorn et al., 2021; Olah et al., 2019). In their business activities, SMEs are confronted with a wide range of business risks (Kot et al., 2020; Lima et al., 2020; Hanggraeni et al., 2019; Hudáková a., 2019; Olah et al., 2019; Zoghi, 2017).

SMEs are characterised by certain features that determine their approach to personnel risk management, which is a complex issue (Dvorsky et al., 2020; Kljucnikov et al., 2019; Olah et al., 2019; Zuzek and Zvirbule, 2018). Meekaewkunchorn et al. (2021) demonstrate the significant and positive impact of the proactiveness and risk-taking ability of SMEs on their business strategy. On the one hand, a higher degree of flexibility is considered to be an SME advantage, while low diversification and exposure to higher risk are considered to be disadvantages (Kljucnikov et al., 2019).

Many researchers have recently focused their attention on human resource management (HRM) and the associated personnel risk, as they consider the human dimension to be a source of competitive advantage (Gonclaves et al., 2019). The negative effect of personnel risk negatively impacts an enterprise's economic performance. Therefore, personnel risk represents an essential component of business risk that SMEs must address.

The originality and excellence of this research lie in the examination of entrepreneurs' attitudes in the SME sector in Slovakia. As part of this research, a significant sample of respondents and relevant data in personnel risk management were obtained.

The structure of the article is as follows. In the theoretical section, other scholars' opinions about the researched field are presented, and the scientific gap defined. The following section defines the aim of the research, methodology, and description of the empirical data. The section is followed by the results of the study and a short discussion thereof. The integrated research results, the limits of the research, and the focus for further research are presented in the final section.

\subsection{Literature review}

Regardless of size, every enterprise has to deal with some risks that can negatively affect their performance. Lima et al. (2020) stress that SMEs are confronted with risks more often than large companies, and that it is in the former's best interest to address the risk in terms of its prediction, assessment, and management. The authors also point out that SMEs cannot implement the risk management guidelines intended for large companies due to SMEs' specific circumstances (for example access to resources), a contention that is supported by Ohal et al. (2019). Wuen et al. (2020) lend further support to this assertion in the context of HRM. Cera et al. (2019) observe that an enterprise's exposure to risk can have negative consequences if the 
enterprise is not prepared. Olah et al. (2019) emphasise that most risks are borne by SMEs; however, appropriate management of risks can transform them into competitive advantage. Thus, risk management may be assumed to have become an essential part of SME management. Songling et al. (2018) identified a significant and positive relationship between SMEs' performance (financial and non-financial) and risk management. The authors identified this benefit especially in emerging economies, and considered risk management as a source of competitive advantage because it reduced potential costs. Numerous barriers to risk management in the SME sector have been identified: a lack of managerial knowledge, demographic factors (such as age, gender, and education), personality (attitude to risk), and organisational structure (Zoghi, 2017).

Korcmaros and Simova (2018) regard financial risks as constituting a significant part of SMEs' risk exposure. They associate SMEs' financial risk exposure with their limited access to funding for their activities. Dvorsky et al. (2020) added legal, market, operational, and personnel risks (which, in this study, is presented as employees' engagement in the performance of an enterprise) to SMEs' risk exposure.

Fetisovova et al. (2012) demonstrate that SMEs are more exposed to risks than larger enterprises. The authors claim that the higher risk rate of SMEs is a consequence of a low degree of diversification, low capital strength, limited access to capital, the form of owner liability, and lower managerial qualification.

In this context, Ivanova (2017) observes that SMEs generally have limited access to external sources of financing innovations. In Slovakia, the most used source of financing innovations among enterprises is profit; this was reported by $50 \%$ of the Slovak enterprises in the study. The author contends that access to external sources of funding depends on an enterprise's size. A similar conclusion was reached by Hvolková et al. (2019), who examined and compared innovation barriers in Slovakia in 2014 and 2017.

Wuen et al. (2021) add informal structure and a preference for generalists over specialists as other sources of SMEs' risks that influence their performance. Kozubikova et al. (2021) recognises different types of business risk: lack of strategic focus, lack of thinking in a strategic context, insufficient planning, and poor flexibility. Haviernikova and Kordos (2019) identified business risk as the most significant, and classified it into legal risk, loss of reputation, and personnel risk. Personnel risk can be defined as the probability that, due to human factor failure, undesired effects on business activities will occur.

The issue of personnel risk management has received less attention from scholars than other types of managerial risks. As has been mentioned, employees represent important capital for an enterprise, which can significantly influence its performance and success (Gonclaves et al., 2019). Due to the importance of employees, Kozubikova et al. (2021) pointed out the negative consequences of personnel risks in terms of employees' activity or passivity.

SMEs' personnel management plays an important role in this process. According to Uyar and Deniz (2012), an SME's focus on HRM helps it sustain its development. Therefore, poor personnel management can negatively affect enterprise performance and proper functioning. Wuen et al. (2021) highlight the importance of personnel management in the SME sector in terms of managing and motivating employees to realise their full potential.

Hudáková (2009) lists the most important sources of personnel risk in an enterprise: a high employee turnover rate, employees' error rate in the transformation process, inadequate controls for employees, increased instances of absenteeism and incapacitated employees, insufficient employee qualifications, an inadequate remuneration system, decreased work morale and discipline, insufficient motivation for employees, time stress, and employee overload. 
Olah et al. (2019) identify the most dangerous risks related to personnel management as employees' errors, shortage of skilled employees, insufficient job description, employees' adaptation, employee motivation, and employees' social relationships.

The International Labour Organization (2019) identifies an important 'human-centred' approach to employees from the points of view of businesses and governments. The document prioritises the achievement and promotion of employees' skills; additionally, it emphasises sufficient legislation and a specialised institution to provide guidelines on the issue of human resources. As in other studies (Nguyen et al., 2021; Goncalves et al., 2019; Klujcnikov et al., 2016), the emphasis in this document is on the importance of skilled employees in the context of an enterprise's performance. It may be concluded that HRM has assumed an essential role in SME management. According to Zuma (2018), HRM turns human resources into human capital to significantly affect an organisation's success. The critical issue is finding the right person for the right work position; most entrepreneurs are aware that a skilled employee is a gift to the company. However, there are other risks associated with HRM: employee turnover, employee error rate, uneducated employees, low engagement, insufficient controls, injury, etc.

Moreover, all these personnel risks could negatively influence an enterprises' sustainability and performance because of the critical position of employees in business success (Olah et al., 2019). In this respect, SME managers must be aware that this issue requires constant attention, comprehensive analysis, and effective management because, as stated in a Deloitte report (2018), one of the most significant business risks is people's behaviour. If we generalise Meekaewkunchorn et al.'s (2021) results, proactiveness and risk-taking ability are equally essential for a human resource strategy.

In this context, Heilmann et al. (2018) emphasise the need for a proactive management style that efficiently invests in human resources to swiftly adapt to positive changes to meet customers' needs. The key attitude for SMEs is looking to the future, identifying the silent signals, motivating learning, and managing competencies based on practical solutions.

\section{Aim, Methods, and Data}

The aim of the study is to present and quantify significant factors of personnel risk in the SME sector. Part of the goal of the study is to compare entrepreneurs' approaches to these factors based on company size, entrepreneurs' education, and the age of the entrepreneur/manager.

The empirical research was conducted in Slovakia via an online questionnaire. The data were collected from September 2020 to January 2021, via an online questionnaire published on survio.com. By random selection, 10100 SMEs from Slovakia were obtained for the sample. The 'Cribis' database in the Slovak Republic was used to define the primary sample of respondents and their contact details. The selected enterprises were contacted by email and requested to complete the published questionnaire. The average return rate for the questionnaire was $2.52 \%$. The questionnaire could be completed only by the owner or top manager of an SME (hereafter, respondent).

The total number of respondents was 255 , of which $76 \%$ were owners and $24 \%$ were managers (hereafter, entrepreneurs). The limited liability companies constituted the majority of the respondents $-76.86 \%(\mathrm{~N}=196)$. From the business sector, the highest response rate was from the service sector $-60.78 \%(\mathrm{~N}=115)$. Most of the enterprises operated in the Bratislava region $-24.71 \%(\mathrm{~N}=63)$.

The composition of the sample was as follows: in terms of size, micro-sized enterprises constituted $61 \%$ of the respondents, $24 \%$ were small-sized enterprises, and $15 \%$ medium- 
sized enterprises; in terms of education of the entrepreneurs, $4 \%$ of the respondents reported secondary education without graduation, $22 \%$ reported secondary education with graduation, $4 \%$ reported a 1 st degree of university education, $63 \%$ a 2 nd grade of university education, and $9 \%$ a 3rd grade of university education.

The following statistical hypotheses were formulated, based on theoretical knowledge and discussions with selected entrepreneurs from the SMEs sector:

H1: There are statistically significant differences in the structure of the answers for the assessment of the statement, ST1: I consider personnel risk in the enterprise as acceptable, and it does not negatively affect my/our entrepreneurship based on:

H1A: the size of the company,

H1B: the education of the manager/owner of the enterprise, and

H1C: the age of the manager/owner of the enterprise.

H2: There are statistically significant differences in the structure of the answers for the assessment of ST2: The rate of employee turnover is low, and it does not have a negative impact on my/our entrepreneurship based on:

$\mathrm{H} 2 \mathrm{~A}$ : the size of the company,

$\mathrm{H} 2 \mathrm{~B}$ : the education of the manager/owner of the enterprise, and

$\mathrm{H} 2 \mathrm{C}$ : the age of the manager/owner of the enterprise.

H3: There are statistically significant differences in the structure of the answers for the assessment of ST3: The employee error rate is low and does not have a negative impact on entrepreneurship based on:

H3A: the size of the company,

H3B: the education of the manager/owner of the enterprise, and

$\mathrm{H} 3 \mathrm{C}$ : the age of the manager/owner of the enterprise.

H4: There are statistically significant differences in the structure of the answers for the assessment of ST4: Our employees attempt to improve their performance, and work competitiveness prevails among them according to:

H4A: the size of the company,

H4B: the education of the manager/owner of the enterprise, and

$\mathrm{H} 4 \mathrm{C}$ : the age of the manager/owner of the enterprise.

Additionally, statistically significant differences in the respondents' positive answers to each hypothesis will be compared. The statistical hypotheses were tested using descriptive statistics (percentages) and Pearson's statistics (chi-square and Z-score). These methods allow a quantification of the statistically significant differences in the defined sample of respondents. According to Reznakova (2007), chi-square tests for goodness of fit. The hypothesis, $H_{0}: \pi_{i}=$ $\pi_{i}, 0$, where $i=1,2, \cdots, K$ (with $\mathrm{K}$ the number of categories and $\sum \pi_{i}, 0=1$ ) is compared to the alternative hypothesis, $H_{1}: H_{0}$ is rejected. If the consant factors, $\pi_{i}, 0$, are the same, we can formulate the null hypothesis as $H_{0}: \pi_{1}=\pi_{2}=\cdots=\pi_{k}$. For $\pi_{i} \geq 5$, the statistical formula for chi-square is given by:

$$
\chi^{2}=\sum_{i=1}^{K} \frac{\left(n_{i}-n \pi_{i}, 0\right)^{2}}{n \pi_{i}, 0},
$$

where $n \pi_{i}, 0$ are the theoretical (expected) observations for a category in a random sample of $n$. This random variable has, in the event that $H_{0}$ is correct, a chi-square distribution of the quantity with $(K-1)$ degrees of freedom, i.e. $\chi^{2}[k-1]$. The calculated value of the test statistic, $\chi^{2}$, is compared to the quantile, $[\mathrm{K}-1]$. 
The p-value of chi-square was calculated as follows. A contingency table was drawn, using the SAS JMP software, version 16.0, of the value of the chi-square distribution $\left(\chi^{2}\right)$ statistic and the appropriate degrees of freedom; the probability was then determined whether the variance of the observed values from the expected values was caused by chance. The calculated value of the probability was compared to the significance level of $\alpha=0.05$ (as the lower critical threshold of the probability to reject $H_{0}$ ) to evaluate the hypothesis.

\section{Results}

The results of the empirical research and their statistical analysis are presented in the following tables (Tables 1-4).

Table 1: I consider personnel risk in the enterprise as adequate, and it does not negatively affect my/our entrepreneurship (ST1)

\begin{tabular}{|c|c|c|c|c|c|c|c|c|c|}
\hline ST1 & & $\mathbf{A}$ & & B & & $\mathbf{C}$ & & & \\
\hline & $\mathrm{N}$ & $\begin{array}{l}\text { Micro } \\
\text { enterprise }\end{array}$ & $\begin{array}{l}\text { Small, } \\
\text { mediu } \\
\mathrm{m} \\
\text { enterpr } \\
\text { ise }\end{array}$ & $\begin{array}{l}\text { Secondary } \\
\text { education }\end{array}$ & $\begin{array}{l}\text { University } \\
\text { education }\end{array}$ & $45-$ & $45+$ & $\begin{array}{l}\text { Z-score } \\
\text { A }\end{array}$ & $\begin{array}{l}\text { p- } \\
\text { value } \\
\text { A }\end{array}$ \\
\hline $\begin{array}{l}\text { 1. Strongly } \\
\text { agree }\end{array}$ & 22 & 16 & 6 & 12 & 15 & 7 & 15 & 0.82 & 0.41 \\
\hline 2. Agree & 84 & 52 & 32 & 10 & 69 & 29 & 55 & $\begin{array}{l}\mathrm{Z} \text { - } \\
\text { score B }\end{array}$ & $\begin{array}{l}\text { p- } \\
\text { value } \\
\text { B }\end{array}$ \\
\hline $1+2$ sum & 106 & 68 & 38 & 22 & 84 & 36 & 70 & -1.00 & 0.32 \\
\hline $1+2$ sum in $\%$ & $\begin{array}{l}41 . \\
57\end{array}$ & 43.59 & 38.38 & 36.07 & 43.30 & $\begin{array}{l}43 . \\
37\end{array}$ & $\begin{array}{l}40 . \\
70\end{array}$ & $\begin{array}{l}\text { Z-score } \\
\text { C }\end{array}$ & $\begin{array}{l}\text { p- } \\
\text { value } \\
C\end{array}$ \\
\hline 3. Neutral & 68 & 45 & 23 & 10 & 52 & 22 & 46 & 0.41 & 0.68 \\
\hline 4. Disagree & 69 & 38 & 31 & 25 & 50 & 23 & 46 & & \\
\hline $\begin{array}{l}\text { 5. Strongly } \\
\text { disagree }\end{array}$ & 12 & 5 & 7 & 4 & 8 & 2 & 10 & & \\
\hline Sum & 255 & 156 & 99 & 61 & 194 & 83 & 172 & & \\
\hline Chi-square & & 4.98 & & 17.66 & & 1.55 & & & \\
\hline p-value & & 0.29 & & 0.001 & & 0.82 & & & \\
\hline
\end{tabular}

Source: Processed by authors

Of the respondents, $41.5 \%$ agreed with the statement, ST1, $26.67 \%$ of them were neutral, while $31.76 \%$ did not agree with the statement. These results could not be considered as positive.

Of the respondents who agreed with ST1 (I consider personnel risk in the enterprise as acceptable, and it does not negatively affect my/our entrepreneurship), $36.07 \%$ were entrepreneurs with secondary education and $43.59 \%$ were from micro-sized enterprises. The results point to the existence of statistically significant differences in the structure of the respondents' answers in B: education of respondents $(\chi 2=17.66 ; p-$ value $=0.001)$. 
The p-value of the Z-score suggests that the differences in the positive attitudes of the respondents to ST1 are not statistically significant.

Thus, it may be stated that there are no statistically significant differences in the answers for the assessment of ST1 (I consider personnel risk in the enterprise as acceptable, and it does not negatively affect my/our entrepreneurship).

H1A was not supported.

H1B was partially supported.

H1C was not supported.

Table 2: The rate of the employees' fluctuation is low, and it does not have a negative impact on my/our entrepreneurship

\begin{tabular}{|c|c|c|c|c|c|c|c|c|c|}
\hline ST2 & & $\mathbf{A}$ & & B & & $\mathbf{C}$ & & & \\
\hline & $\mathrm{N}$ & $\begin{array}{l}\text { Micro } \\
\text { enterprise }\end{array}$ & $\begin{array}{l}\text { Small } \\
\text { mediu } \\
\mathrm{m} \\
\text { enterpr } \\
\text { ise }\end{array}$ & $\begin{array}{l}\text { Secondary } \\
\text { education }\end{array}$ & $\begin{array}{l}\text { University } \\
\text { education }\end{array}$ & $45-$ & $45+$ & $\begin{array}{l}\text { Z- } \\
\text { score A }\end{array}$ & $\begin{array}{l}\text { p-value } \\
\text { A }\end{array}$ \\
\hline $\begin{array}{l}\text { 1. Strongly } \\
\text { agree }\end{array}$ & 55 & 35 & 20 & 9 & 46 & 16 & 39 & 0.19 & 0.85 \\
\hline 2. Agree & 86 & 52 & 34 & 18 & 68 & 29 & 57 & $\begin{array}{l}\text { Z- } \\
\text { score B }\end{array}$ & $\begin{array}{l}\text { p- } \\
\text { value } B\end{array}$ \\
\hline $1+2$ sum & 141 & 87 & 54 & 27 & 114 & 45 & 96 & -1.99 & 0.047 \\
\hline $1+2 \operatorname{sum} \%$ & $\begin{array}{l}55 . \\
29\end{array}$ & 55.77 & 54.55 & 44.26 & 58.76 & $\begin{array}{l}54 . \\
22\end{array}$ & $\begin{array}{l}55 . \\
81\end{array}$ & $\begin{array}{l}\text { Z- } \\
\text { score C }\end{array}$ & $\begin{array}{l}p \text { - } \\
\text { value } C\end{array}$ \\
\hline 3. Neutral & 55 & 35 & 20 & 13 & 42 & 19 & 36 & -0.24 & 0.81 \\
\hline 4. Disagree & 43 & 25 & 18 & 13 & 30 & 15 & 28 & & \\
\hline $\begin{array}{l}\text { 5. Strongly } \\
\text { disagree }\end{array}$ & 16 & 9 & 7 & 8 & 8 & 4 & 12 & & \\
\hline sum & 255 & 156 & 99 & 61 & 194 & 83 & 172 & & \\
\hline Chi-square & & 0.63 & & 9.07 & & 0.98 & & & \\
\hline p- value & & 0.96 & & 0.06 & & 0.91 & & & \\
\hline
\end{tabular}

Source: Processed by authors

Of the respondents, $55.29 \%$ agreed with the statement, ST2, $21.57 \%$ them were disinterested, while $23.14 \%$ did not agree with the statement. These results could not be considered as positive.

Of the respondents who agreed with ST2 (Employee turnover is low, and it does not have a negative impact on my/our entrepreneurship), $44.26 \%$ had secondary education and $58.76 \%$ had university education). The results suggest no statistically significant differences in the structure of the respondents' answers in respect of all the factors examined.

The p-value of the Z-score suggests differences in the positive attitudes of the respondents. The respondents with university education significantly agreed more with ST2 than those with secondary education $(58.76 \% / 44.26 \%)$. 
Thus, it may be stated that there are no statistically significant differences in the answers for the assessment of ST1 (I consider personnel risk in the enterprise as acceptable, and it does not negatively affect my/our entrepreneurship).

H2A was not supported.

H2B was partially supported.

$\mathrm{H} 2 \mathrm{C}$ was not supported.

Table 3: The error rate of the employees is low and does not have a negative impact on entrepreneurship (ST3)

\begin{tabular}{|c|c|c|c|c|c|c|c|c|c|}
\hline ST3 & & $\mathbf{A}$ & & B & & $\mathbf{C}$ & & & \\
\hline & $\mathrm{N}$ & $\begin{array}{l}\text { Micro } \\
\text { enterprise }\end{array}$ & $\begin{array}{l}\text { Small } \\
\text { mediu } \\
\mathrm{m} \\
\text { enterpr } \\
\text { ise }\end{array}$ & $\begin{array}{l}\text { Secondary } \\
\text { education }\end{array}$ & $\begin{array}{l}\text { University } \\
\text { education }\end{array}$ & $45-$ & $45+$ & $\begin{array}{l}\text { Z- } \\
\text { score A }\end{array}$ & $\begin{array}{l}\text { p- } \\
\text { value } \\
\text { A }\end{array}$ \\
\hline $\begin{array}{l}\text { 1. Strongly } \\
\text { agree }\end{array}$ & 33 & 23 & 10 & 6 & 27 & 8 & 25 & 0.51 & 0.61 \\
\hline 2. Agree & 106 & 64 & 42 & 25 & 81 & 30 & 76 & $\begin{array}{l}Z \text { - } \\
\text { score B }\end{array}$ & $\begin{array}{l}\text { p- } \\
\text { value } \\
\text { B }\end{array}$ \\
\hline $1+2$ sum & 139 & 87 & 52 & 31 & 108 & 38 & 101 & -0.66 & 0.51 \\
\hline $1+2$ sum in $\%$ & $\begin{array}{l}54 . \\
51\end{array}$ & 55.77 & 52.53 & 50.82 & 55.67 & $\begin{array}{l}45 . \\
78\end{array}$ & $\begin{array}{l}58 . \\
72\end{array}$ & $\begin{array}{l}\mathrm{Z} \text { - } \\
\text { score C }\end{array}$ & $\begin{array}{l}\text { p- } \\
\text { value } \\
C\end{array}$ \\
\hline 3. Neutral & 59 & 38 & 21 & 13 & 46 & 23 & 36 & -1.94 & 0.052 \\
\hline 4.Disagree & 42 & 25 & 17 & 12 & 30 & 16 & 26 & & \\
\hline $\begin{array}{l}\text { 5. Strongly } \\
\text { disagree }\end{array}$ & 15 & 6 & 9 & 5 & 10 & 6 & 9 & & \\
\hline Sum & 255 & 156 & 99 & 61 & 194 & 83 & 172 & & \\
\hline Chi-square & & 4.18 & & 1.95 & & 3.99 & & & \\
\hline p-value & & 0.38 & & 0.75 & & 0.41 & & & \\
\hline
\end{tabular}

Source: Processed by authors

Of the respondents, $54.51 \%$ agree with the statement, ST3, $23.14 \%$ of them were disinterested, and $22.35 \%$ did not agree with the statement. These results could not be considered as positive.

Of the respondents who agreed with ST3 (The employees' error rate is low and does not have a negative impact on entrepreneurship), $45.78 \%$ were 45 years old or younger, while $58.72 \%$ were older than 45 years. The results indicate that there are no statistically significant differences in the structure of the respondents' answers in respect of all the factors examined.

The $\mathrm{p}$-value of the Z-score suggests that the differences in the attitudes to the statement, ST3, are not statistically significant.

Thus, it may be stated that there are no statistically significant differences in the answers for the assessment of ST3: The employees' error rate is low and does not have a negative impact on entrepreneurship, based on company size, education, or respondent age.

H3A was not supported.

H3B was not supported. 
H3C was not supported.

Table 4: Our employees try to improve their performance and work competitiveness prevail among them

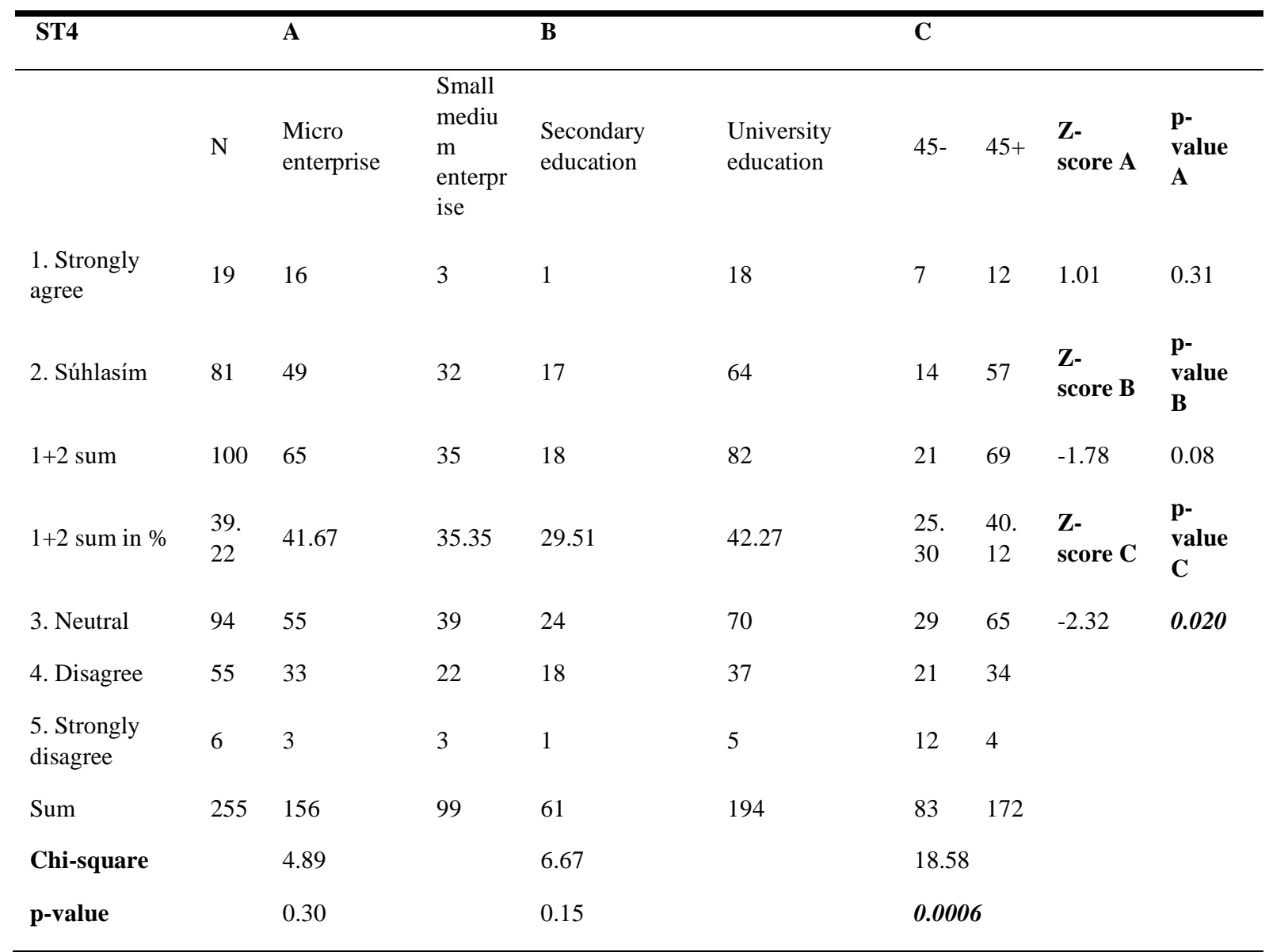

Source: Processed by authors

Of the respondents, $39.22 \%$ agreed with the statement, ST $4,36.86 \%$ of them were neutral, and $23.92 \%$ did not agree with the statement. These results could not be considered as positive.

Of the respondents who agreed with ST4 (Our employees attempt to improve their performance, and work competitiveness prevails among them), $23.50 \%$ were 45 years old or younger, and $42.27 \%$ had university education. The results indicate that there are statistically significant differences in the structure of the respondents' answers in respect of the factor, $\mathrm{C}$ : age of the manager/owner $(\chi 2=18.58 ; p-$ value $=0.0006)$.

The p-value of the Z-score suggests that the differences in the attitudes to the statement, ST4, are statistically significant $(C)$. The entrepreneurs aged over 45 years significantly agreed more with ST4 than younger entrepreneurs.

Thus, it may be stated that there are statistically significant differences in the answers for the assessment of ST4: Our employees attempt to improve their performance, and work competitiveness prevails among them, based on the age of the respondent.

H3A was not supported.

H3B was not supported.

H3C was supported. 


\section{Discussion}

The enterprises' personnel risk was assessed as acceptable by $42 \%$ of the respondents. However, up to $32 \%$ of the respondents assessed the risk as unacceptable, which gives rise to various questions. Of the respondents, $55 \%$ assessed employee turnover as low, and only $23 \%$ thought the opposite. It may be assumed that this factor did not cause significant problems in SMEs. The employees' error rate was relatively low and did not negatively influence the entrepreneurship of the SMEs. Despite this fact, there may other explanations for the SMEs' better performance in respect of this factor.

A relatively small proportion of the respondents (39\%) agreed that their employees attempted to improve their performance, and that work competitiveness prevailed among them. The fact that some respondents (up to $37 \%$ ) could not clearly formulate their opinion could be considered problematic. One possible explanation could be their inability to assess their employees; another could be simply that they were not concerned with this issue. These results could not be considered as positive. Of all types of challenges, managing people is among the riskiest and most critical areas for enterprises (Ortlieb and Sieben, 2012), as employees are considered important capital for enterprises, with a significant influence on SMEs' performance (Gonclaves et al., 2019).

SMEs are generally known for their informal, spontaneously emerging, and reactive approach to HRM (Psychogios et al., 2016), and do not have formal HRM functions; SME managers deal with HRM practices in addition to their core managerial functions, and are rarely formally trained in the implementation of HRM procedures. The managers often do not have HRM structures and formal HRM policies developed (Heilmann et al., 2018).

According to Hudakova et al. (2019), personnel risks are often underestimated in the current business environment. This was demonstrated by the results of their study, conducted in 2017, which was based on a sample of 487 SMEs in Slovakia. In this study, personnel risks were ranked the fourth most serious risks for SMEs. The managers and the owners of SMEs are often perceived as sources of personnel risks, which include unequal qualifications of employees, high employee turnover rate, decreased work morale, lack of discipline, and employee errors. According to the authors, SME owners and managers are aware of staffing risks but do not pay adequate attention to them.

It is evident that small enterprises need to adopt adequate risk management strategies to deal with the threats and challenges that arise from internal and external sources, as these have the potential to severely threaten the firms' survival (Islam and Tedford, 2012; Verbano and Venturini, 2013). The implementation of a risk management process enables the evaluation of risks, which then allows for calculated and acceptable risks to be taken (Hudakova et al., 2018).

In this context, SME owners and managers must be able to eliminate the impact of personnel risk on their enterprises.

\section{Conclusions}

The aim of the study is to present and quantify significant factors of personnel risk in the SME sector. Part of the objective is to compare entrepreneurs' attitudes to personnel risk factors based on company size, entrepreneurs' education, and the age of managers/owners.

The study revealed that personnel risk constituted a vital entrepreneurship risk for SMEs, because up to $32 \%$ of all the respondents considered this risk unacceptable. Neither employee turnover nor employees' error rate posed a significant problem for SMEs at the time of the study. Only a small proportion of the respondents agreed that their employees attempted to improve their performance, and that work competitiveness prevailed among them. 
The study confirmed some differences in the structure of the entrepreneurs' attitudes based on their education and age. There are also differences in the entrepreneurs' positive attitudes towards individual claims based on their education and age. This study has some limitations: one is the limited, although representative, sample of respondents; the other is the timing of the research in terms of the phase of the economic cycle. Nevertheless, the results show that the issue of personnel management in the effective management of personnel risks in an SME environment can be an interesting area for scientific research.

Author contributions: All authors listed have made a substantial, direct and intellectual contribution to the work, and approved it for publication.

\section{Data Availability Statement:}

The data presented in this study are available on request from the corresponding author. The data are not publicly available due to own empirical research of corresponding author.

Conflicts of Interest: The authors declare no conflict of interest.

\section{References}

Deloitte. (2008). Taking the Reins: HR's opportunity to play a leadership role in governance, risk management and compliance. CHRO Strategist and Steward Series. Deloite Consuling. Midtown: Manhatan

Çera, G., Belás, J., \& Strnad, Z., (2019). Important factors which predict entrepre-neur's perception in business risk. Problems and Perspectives in Management, 17(2), 415-429.

Dvorsky, J., Kozubikova, L., \& Bacova, B. (2020). The perception of business risks by SMEs in the Czech Republic. Central European Business Review, 9(5), 25-44.

Fetisovová, E., Hucová, E., Nagy, L., \& Vlachynský, K. (2012). Aktuálne problémy financií malých a stredných podnikov. Bratislava: Ekonóm.

Goncalves, J, M., Ferreira, F. A. F., Ferreira, J. J. M., \& Farinha, L. M. C. (2019). A multiple criteria group decision-making approach for the assessment of small and medium-sized enterprise competitiveness. Management Decision, 5(2), 480-500.

Hanggraeni, D., Ślusarczyk, B., Sulung, L. A. K., \& Subroto, A. (2019). The impact of internal, external and enterprise risk management on the performance of micro, small and medium enterprises. Sustainability, 11(7), 2172.

Havierniková, K., \& Kordoš, M. (2019). The SMEs'perception of financial risks in the context of cluster cooperation. Quantitative Finance and Economics, 3(3), 586-607.

Heilmann, P., Forsten-Astikainen, R., \& Kultalahti, S. (2018). Agile HRM Practices of SMEs. Journal of Small Business Management, 1-11 https://doi.org/10.1111/jsbm.12483

Hudáková, M., Buganová, K. Míka V. T., \& Masár, M. (2019). Manažment rizík malých a stredných podnikov. Žilina: EDIS.

Hudakova, M., Masar, M., Luskova, M. \& Patak, M. R. (2018). The Dependence of Perceived Business Risks on the Size of SMEs. Journal of Competitiveness, 10(4), 54-69.

Hudáková, M. (2009). Model riadenia rizík v priemyselnom podniku s využitím strategického kontrolingu. Žilina: EDIS.

Hvolkova, L., Klement, L., Klementova, V., \& Kovalova, M. (2019). Barriers hindering innovations in small and medium-sized enterprises. Journal of Competitiveness, 11(2), 51-67.

International Labour Organization. (2019). Global Commission on the Future of Work - Work for a a brighter future. https://www.ilo.org/wcmsp5/groups/public/—dgreports/—cabinet/documents/publication/wcms 662410.pdf

Ivanová, E. (2017). Barriers to the development of SMEs in the Slovak Republic. Oeconomia Copernicana, 8(2), $255-272$.

Islam, A., \& Tedford, D. (2012). Risk determinants of small and medium-sized manufacturing enterprises (SMEs) - an exploratory study in New Zealand. Journal of Industrial Engineering International, 8(1), 1. 


\section{The perception of significant aspects of personnel risk in the management of SMEs \\ Authors: Jaroslav Belas, Jr., Katarina Zvarikova, Josef Marousek Zdenko Metzker}

Kljucnikov, A., Belas, J., Kozubikova, L., \& Pasekova, P. (2016). The entrepreneurial perception of SME business environment quality in the Czech Republic. Journal of Competitiveness, 8(1), 66-78.

Ključnikov, A., Civelek, M., Čech, P., \& Kloudová, J. (2019). Entrepreneurial orientation of SMEs' executives in the comparative perspective for Czechia and Turkey. Oeconomia Copernicana, 10(4), 773-795.

Korcsmaros, E., \& Simova, M. (2018). Factors affecting the business environment of SMEs in Nitra region in Slovakia. Oeconomia Copernicana, 9(2), 309-331.

Kot, S., Ul Haque, A., \& Baloch, A. (2020). Supply chain management in SMEs: Global perspective. Montenegrin Journal of Economics, 16(1), 87-104.

Kozubíková, L., Homolka, L. \& Kristalas, D. (2017). The effect of business environment and entrepreneurs' gender on perception of financial risk in the smes sector. Journal of Competitiveness, 9(1), 36-50.

Kozubikova, L., Zamečnik, R., \& Vystupova, L. (2021). The perception of human resource risks in the V4 countries. Polish Journal of Management Studies, 21(2), 210-222.

Lima, P.F.D., Crema, M., \& Verbano, C. (2020). Risk management in SMEs: A systematic literature review and future directions. European Management Journal, 38(1), 78-94.

Meekaewkunchorn, N., Szczepańska-Woszczyna, K., Muangmee, C., Kassakorn, N., \& Khalid, B. (2021). Entrepreneurial orientation and SME performance: The mediating role of learning orientation. Economics \& Sociology, 14(2), 294-312.

Nguyen, P. V., Nguyen, L. T., Van Doan, K. N., \& Tran, H. Q. (2021). Enhancing emotional engagement through relational contracts, management receptiveness, and employee commitment as a stimulus for job satisfaction and job performance in the public sector. Equilibrium. Quarterly Journal of Economics and Economic Policy, 16(1), 203-224.

Olah, J., Virglerova, Z., Popp, J., Kliestikova, J., \& Kovacs, S. (2019). The assessment of non-financial risk sources of SMES in the V4 countries and Serbia. Sustainability, 11(17), 4806.

Ortlieb, R., \& Sieben, B. (2012). How to safeguard critical resources of professional and managerial staff: Exploration of a taxonomy of resource retention strategies. International Journal of Human Resource Management, 23(8), 1688-1704.

Psychogios, A. G., Szamosi, L. T., Prouska, R. \& Brewster, C. (2016). A three-fold framework for understanding HRM practices in South-Eastern European SMEs. Employee Relations, 38 (3). 310-331.

Rocha, E. A. G. (2012). The impact of the business environment on the size of the micro, small and medium enterprise sector; Preliminary findings from a cross-country comparison. Procedia Economics and Finance, 4 , 335-349.

Řezanková, H. (2007). Analýza dat z dotazníkových šetření. Praha: Professional Publishing.

Septimiu, S. (2020). Transition to Industry 4.0 in the Visegrád Countries European Economy. Economic Briefs 052.

Songling, Y., Ishtiaq, M., \& Anwar, M. (2018). Enterprise risk management practices and firm performance, the mediating role of competitive advantage and the moderating role of financial literacy. Journal of Risk and Financial Management, 11(3), 35.

Uyar, A. S., \& Deniz, N. (2012). The perceptions of entrepreneurs on the strategic role of human resource management. Procedia - Social and Behavioral Sciences, 58, 914-923.

Verbano, C., \& Venturini, K. (2013). Managing risks in SMEs: A literature review and research agenda. Journal of Technology Management and Innovation, 8(3), 186-197.

Zuzek, D. K., Zvirbule, A. (2018). Corporate social responsibility as a chance for sustainable social-economic development of small and medium enterprises in Poland and Latvia. Economic Science for Rural Development, 47, 424-432.

Zoghi, F. S. (2017). Risk management practices and SMEs: An empirical study on Turkish SMEs. International Journal of Trade, Economics and Finance, 8(2), 123-127.

Zuma, S. K. (2018). HR Governance for sustainable human resource development: Evidence from private sector of Bangladesh. European Journal of Business and Management, 10(12), 207-216.

Wuen, C. H., Ibrahim, F., \& Fingim, K. J. (2020). The impact of human resource management practices on smes performance: An exploratory study in Brunei Darussalam. International Journal of Asian Business and Information Management, 11(2), 68-87. 